\title{
Visualization of Tawang Alun Temple Based Augmanted Reality as a Representation of Ancient Relics in Sedati Sidoarjo
}

\section{Visualisasi Candi Tawang Alun Berbasis Augmanted Reality Sebagai Representasi Peninggalan Purba Di Sedati Sidoarjo}

\author{
Aliful Fatikh Pulunggono Suseta ${ }^{1}$, Ade Eviyanti $^{2}$ \\ $\left\{\right.$ alifulfatikhps@gmail.com ${ }^{1}$, adeeviyanti@umsida.ac.id $\left.{ }^{2}\right\}$ \\ Program Studi Informatika, Fakultas Sains dan Teknologi, Universitas Muhammadiyah Sidoarjo ${ }^{12}$
}

\begin{abstract}
Tawangalun Temple is one of the heritage temples of the Majapahit Kingdom in Sidoarjo Regency which is located in Buncitan Village, Sedati District. Based on the analysis of problems in the field of historical construction, Tawang temple still has little information in digital form, so that little information is visually packaged in digital, resulting in a lack of public interest in accessing information. The system development research method used is an action research research design where the research is carried out by designing the Tawang Alun Temple AR application and implementing the design. This research will create augmented reality by recommending locations that can help all people, from school children to students and the general public, displaying the Tawang Alun Temple site. This application will be able to display $3 D$ objects in the form of the Tawang Alun temple.
\end{abstract}

Keywords: Augmented Reality; Tawang Alun Temple

Abstrak Candi Tawangalun merupakan salah satu candi peninggalan Kerajaan Majapahit di Kabupaten Sidoarjo yang terletak di Desa Buncitan, Kecamatan Sedati. Berdasarkan analisis permasalahan di bidang konstruksi sejarah, candi Tawang masih memiliki sedikit informasi dalam bentuk digital, sehingga sedikit informasi yang dikemas secara visual dalam digital, sehingga kurangnya minat masyarakat dalam mengakses informasi. Metode penelitian pengembangan sistem yang digunakan adalah rancangan penelitian action research dimana penelitian dilakukan dengan merancang aplikasi AR Candi Tawang Alun dan menerapkan rancangan tersebut. Penelitian ini akan menciptakan augmented reality dengan merekomendasikan lokasi yang dapat membantu semua kalangan, mulai dari anak sekolah hingga mahasiswa dan masyarakat umum, menampilkan situs Candi Tawang Alun. Aplikasi ini akan mampu menampilkan objek 3D berupa candi Tawang Alun.

Kata kunci : Augmented Reality; Candi Tawang Alun

\section{PENDAHULUAN}

Struktur sejarah, simbol warisan perjuangan yang terkandung dalam peristiwa sejarah, sangat rapuh jika tidak dijaga dengan baik. rusak atau tidak sedap dipandang. Masyarakat harus menjaga dan memelihara bangunan bersejarah atau cagar alam agar selalu memiliki nilai sejarah tersendiri. Bangunan bersejarah adalah bangunan yang memiliki nilai nyata terhadap waktu, estetika, fungsi, peristiwa, dan keunikannya. [1].

Candi Tawangalun salah satu bentuk peninggalan Kerajaan Majapahit di Kabupaten Sidoarjo terletak di Desa Buncitan, Kecamatan Sedati. Dari foto terlihat tidak terlalu bagus dibandingkan dengan candi lainnya, namun jika dilihat dengan detail sepertinya ada tatanan arsitektur candi atau bangunan religi pada masa lalu.[2]. Berdasarkan data di atas, Candi Tawang Alun merupakan salah satu situs sejarah Kerajaan Majapahit pada masa Kesultanan Sidoarjo, dimana sangat sedikit data tentang candi yang disajikan secara digital.

Oleh karena itu dibutuhkan sebuah sistem yang dapat menvisualisasikan candi tawang alun secara digital sehingga adanya aplikasi ini dapat memudahkan semua kalangan baik dari siswa, mahasiswa, dan masyarakat dalam pengenalan situs Candi Tawang Alun. Aplikasi ini nantinya mampu menampilkan objek 3D berupa Candi Tawang Alun.

\section{METODE}

\section{A. Candi Tawang Alun}

Candi Tawangalun salah satu bentuk peninggalan Kerajaan Majapahit di Kabupaten Sidoarjo terletak di Desa Buncitan, Kecamatan Sedati. Dari foto terlihat tidak terlalu bagus dibandingkan dengan candi lainnya, namun jika dilihat dengan detail sepertinya ada tatanan arsitektur candi atau bangunan religi pada masa lalu.[3]. 


\section{B. Augmented Reality}

Augmented Reality dapat didefinisikan sebagai pandangan langsung maupun tidak langsung dari lingkungan dunia nyata yang telah dikembangkan dengan menambahkan informasi yang dihasilkan komputer virtual. Augmented Reality bersifat interaktif dan terdaftar dalam 3D, serta menggabungkan objek nyata dan virtual. Augmented Reality bertujuan menyederhanakan kehidupan pengguna dengan membawa informasi virtual tidak hanya ke lingkungan terdekatnya, tetapi juga ke tampilan tidak langsung dari lingkungan dunia nyata[4].

\section{Marker Based Tracking}

Marker based tracking adalah metode Augmented Reality yang menggunakan marker atau penanda objek dua dimensi yang memiliki suatu pola yang akan dibaca aplikasi melalui kamera, biasanya berupa ilustrasi hitam dan putih persegi dengan batas hitam tebal dan latar belakang putih [5].

\section{Markerless}

Markerless adalah metode Augmented Reality dimana pengguna tidak lagi memerlukan sebuah marker dalam menampilkan objek 3D. Dalam hal ini, marker yang dikenali berupa posisi perangkat, arah, dan lokasi [6].

\section{E. Blender 3D}

Blender 3D adalah rangkaian grafik 3D sumber terbuka, yang mampu memodelkan, merender, animasi, mengomposisikan video, fitur pembuatan game. dan menghidupkan lingkungan 3D. Program Blender 3D tersedia di platform UNIX: SGI Irix, Sun Solaris, Ubuntu, Windows dan Mac[7].

\section{F. Unity}

Unity adalah lingkungan 3D lintas platform yang dengan editor pengembangan yang ramah bagi pengguna. Unity terdiri dari penggabungan berbagai modul untuk mengelola dan merender objek 3D, pencahayaan fisik, animasi, audio, dan lainnya. Setiap modul Unity memiliki antarmuka pengguna atau API dengan sekumpulan kelas (class) dan fungsi, sehingga seluruh sistem dapat diakses melalui skrip yang ditulis menggunakan bahasa pemrograman $\mathrm{C \#}$ atau $\mathrm{C}$ sharp [8].

\section{G. Vuforia}

Vuforia merupakan library pembangunan aplikasi berbasis Augmented Reality yang dikembangkan oleh perusahan Qualcomm. Penggunaan Vuforia SDK gratis oleh penggunanya apabila masih dalam tahap pengembangan dan memenuhi syarat dan ketentuan yang berlaku. Vuforia mendukung berbagai perangkat, mulai dari ponsel genggam hingga kacamata yang dapat dipakai, seperti HoloLens[9].

\section{H. Flowchart}

Flowchart adalah alur yang sistematis tentang proses dan logika dari kegiatan penanganan sebuah informasi atau urutan prosedur dari sebuah program[10]. Flowchart menunjukkan gambaran proses TI yang dibagi menjadi dua kategori, yaitu: System flowchart menunjukkan proses dalam sistem seperti media input, media output dan jenis penyimpanan untuk pengolahan data dan flowchart program yang menggambarkan proses atau urutan instruksi yang diwakili oleh simbol-simbol tertentu.

\section{Usecase}

Use Case adalah unit fungsional transaksi yang berhubungan antara pelaku dan sistem. Tujuan Use Case adalah untuk menunjukkan aktor mana yang berpartisipasi dalam setiap Use Case[11].

\section{J. Sequance}

Sequence Diagram menggambarkan interaksi antara objek, dimana interaksi ditandai dengan pertukaran pesan. Setiap objek diberi pesan yang ditampilkan dengan simbol panah horizontal, berlabel, dan sumbu vertikal yang di asumsikan waktu[12].

\section{K. Activity Diagram}

Activity Diagram dapat menggambarkan aktivitas dalam proses bisnis yang dapat dieksekusi atau dikerjakan oleh sistem. Activity Diagram dapat membantu mengidentifikasi aktivitas yang dikerjakan oleh sistem[13]. 


\section{Metode Pengujian}

Pengujian sistem dilakukan dengan tujuan untuk menemukan kesalahan atau kekurangan pada perangkat lunak yang dibangun. Tujuan pengujian adalah untuk mengetahui apakah perangkat lunak yang dihasilkan memenuhi kriteria sesuai dengan tujuan perancangan perangkat lunak.

Dalam penelitian ini, pengujian yang dilakukan pada sistem adalah pengujian fungsional alfa dan beta. Metode yang digunakan dalam pengujian ini adalah pengujian black box yang berfokus pada pengoperasian sistem yang sedang dibangun.

\section{III.HASIL DAN PEMBAHASAN}

Sistem yang akan dibangun diatas Android, dalam aplikasinya akan dibuat sebuah media penanda yang sebuah marker yang telah ditentukan. Marker akan dikenali oleh kamera, apabila marker tersebut sesuai maka akan menampilkan objek 3D. Objek yang akan ditampilkan adalah candi tawang alun. Dimana alur perancangan sistem akan dijelaskan sebagai berikut: 1.Pengguna menggunakan smartphone untuk mengakses aplikasi. 2. Pengguna mengarahkan frame kamera ke marker, kemudian frame kamera mengidentifikasi marker. 3. Setelah melakukan identifikasi marker, apabila marker sesuai maka objek 3D dapat ditampilkan. 4. Smartphone akan menampilkan objek 3D. 5. Pengguna mendapatkan pengalaman yang lebih realistis dalam menjalakan aplikasi

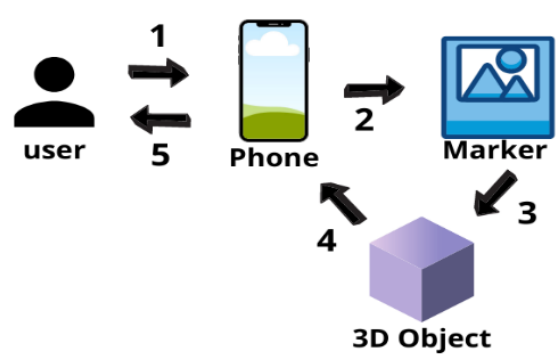

Gambar 1 Desain Rancangan Sistem

Langkah pengambilan sampel data melibatkan perolehan data yang relevan dengan aplikasi, sehingga dibutuhkan data teoritis dengan data lapangan. Berikut ini kegiatan yang dilakukan penulis dalam pengumpulan data. Penelitian dokumenter adalah metode pencarian data dari browsing internet, jurnal, buku atau sumber lain yang berhubungan dengan sistem yang dihasilkan, serta dokumen-dokumen yang diperlukan guna penelitian dan perancangan sistem. Metode observasi langsung adalah metode mengamati secara langsung penanggung jawab pelestarian monumen untuk mendapatkan data-data yang diperlukan untuk penelitian, antara lain: informasi rinci tentang candi dan citra candi. Metode wawancara terdiri dari mengatur wawancara dengan pihak yang terkait langsung dengan masalah yang diteliti dalam tesis ini untuk mendapatkan gambaran dan penjelasan dasar.

Diagram alir merupakan rangkaian bagian yang memaparkan alur program. Pada diagram alur ini dipaparkan urutan prosedur pada sistem aplikasi AR Candi Tawang Alun. 


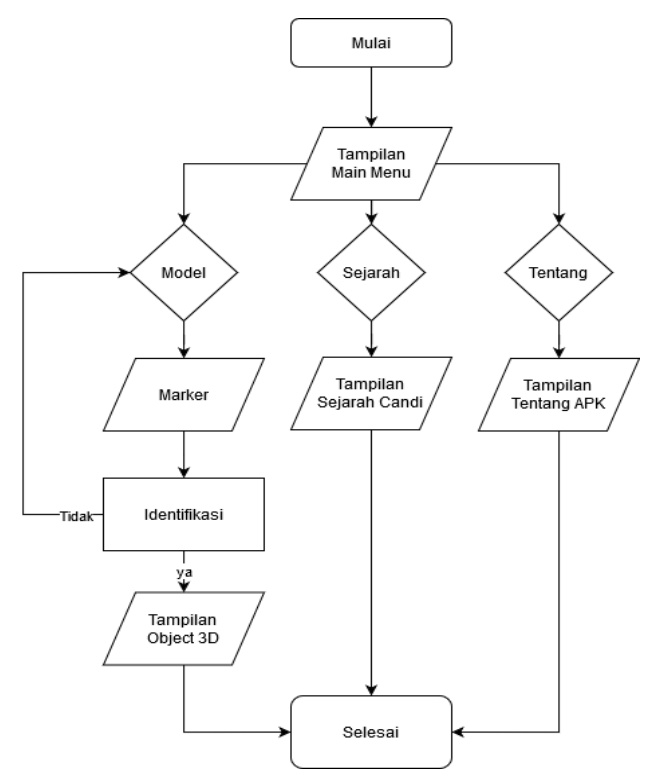

Gambar 2 Flowchart aplikasi Candi Tawang Alun

Tahapan pertama pada aplikasi ini dimulai dengan start, dimana pengguna akan mengakses aplikasi. Pada tahap kedua akan menampilkan menu yang terdapat dalam aplikasi. Tahap ketiga pengguna akan memilih menu, apabila pengguna memilih menu animasi, pengguna diharuskan untuk memasukkan marker. Selanjutnya aplikasi akan mengidentifikasi marker yang telah dimasukkan oleh pengguna. Apabila marker teridentifikasi dan sesuai, maka objek 3D akan tampil. Dan tahap yang terakhir selesai.

Sequence diagram menjelaskan mengenai interaksi antar objek yang diatur dalam tahapan waktu. Setiap tahapan akan dipaparkan pada gambar Sequence Diagram berikut.

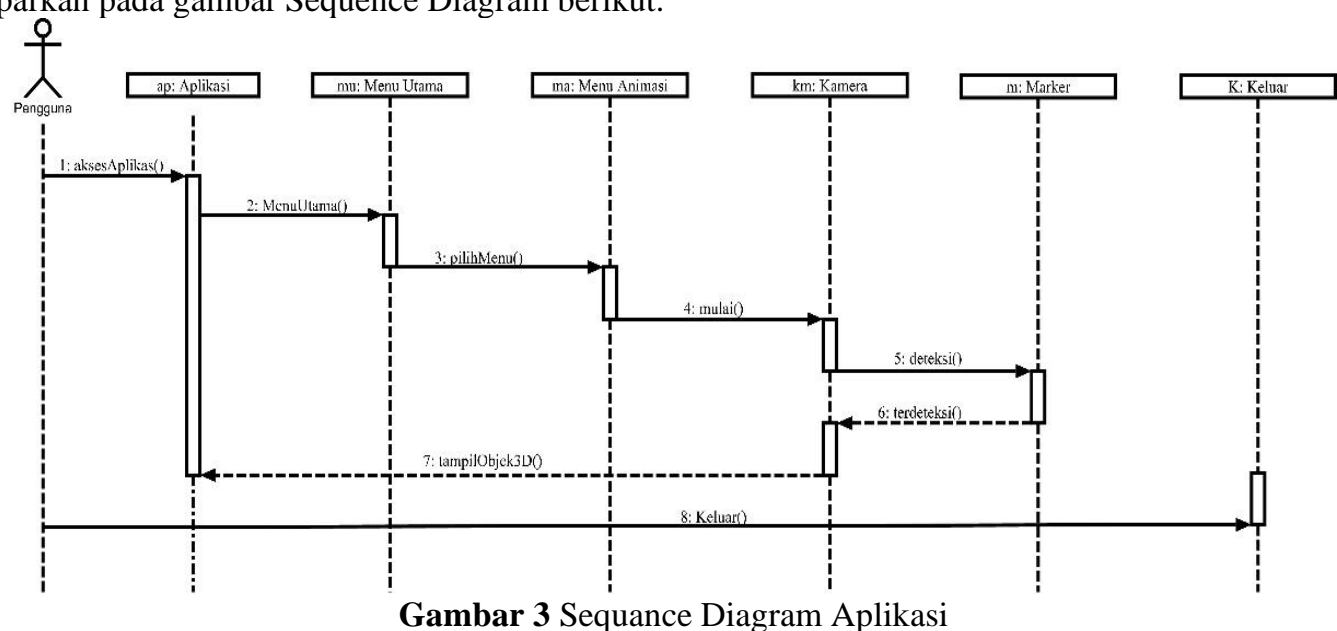

Diagram di atas menunjukkan bahwa pengguna adalah aktor, yang tugasnya berinteraksi dengan komponen sistem. Pertama kali user menjalankan dengan cara mengakses aplikasi tersebut. Kemudian akan menampilkan tampilan menu utama dari aplikasi. User memilih sub menu dari salah satu menu utama, misalnya user memilih menu model. Kemudian aplikasi akan meluncurkan menu dinamis dengan mengalihkan aplikasi ke mode kamera. Kamera akan mendeteksi penanda. Jika penanda terdeteksi dan dipasangkan, sistem akan menampilkan objek 3D. Di bagian bawah sistem ini, user dapat memilih menu keluar jika ingin mengakhiri penggunaan aplikasi.

Use Case Diagram merupakan gambaran secara umum mengenai hubungan antara user dan sistem. 


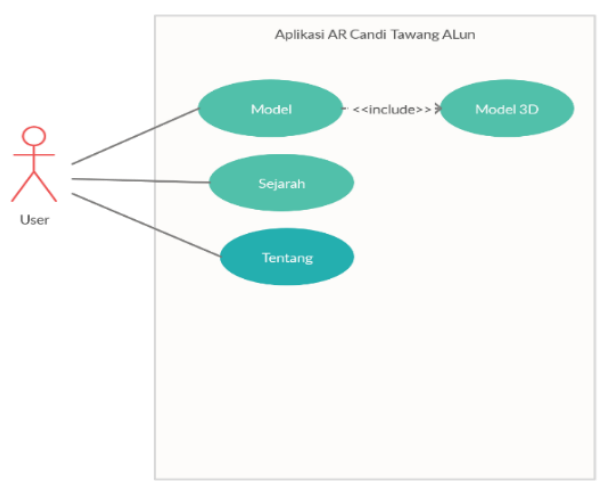

Gambar 4 Use Case

Use Case Diagram ini yang akan digunakan pada aplikasi Augmented Reality candi tawang alun. Use Case Diagram diatas menggambarkan aktivitas yang dapat dikerjakan oleh pengguna. Aktivitas tersebut terdiri dari 4 fitur yang terdapat dalam aplikasi yaitu animasi, panduan, tentang, dan keluar.

Activity Diagram digunakan sebagai menggambarkan alur kerja dari sebuah sistem. Activity Diagram juga menggambarkan aktivitas yang dijalankan oleh sistem bukan pengguna.

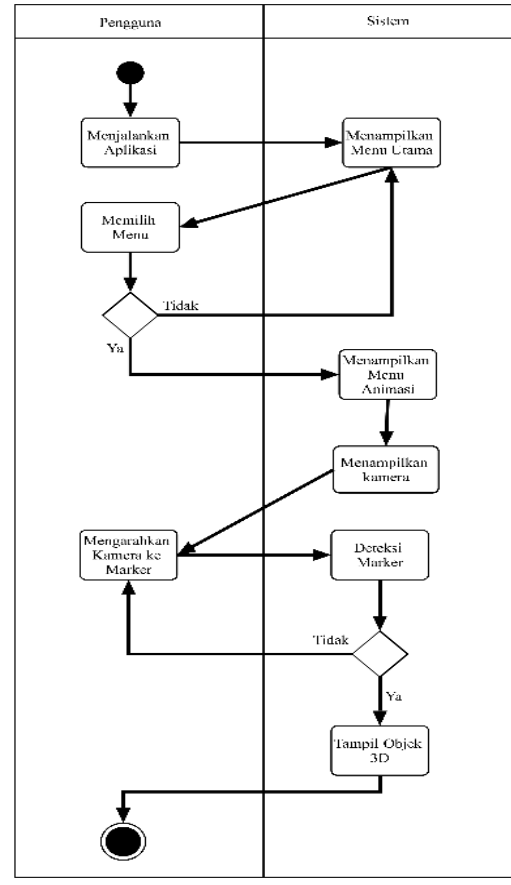

Gambar 5 Activity Diagram

Activity Diagram diatas menunjukkan aktivitas yang dilakukan sistem ketika pengguna menjalankan aplikasi. Ketika pengguna menjalankan aplikasi, maka sistem menampilkan menu utama. Jika pengguna memilih menu animasi makan sistem akan menampilkan menu animasi. Sistem akan mengalihkan aplikasi ke mode kamera, pengguna akan mengarahkan kamera ke marker. Sistem akan mengidentifikasi marker, apabila marker teridentifikasi dan sesuai, maka sistem akan menampilkan objek 3D. Apabila marker tidak terdeteksi atau tidak sesuai maka objek 3D tidak akan tampil. Maka pengguna perlu mengarahkan kamera hingga marker teridentifikasi dan objek 3D muncul. 


\section{IV.KESIMPULAN}

Dari rancangan sistem yang akan dibuat berdasarkan analisa dan penelitian yang sudah dilakukan: Aplikasi ini dirancang untuk menjadi media pengenalan situs Candi Tawang Alun. Fitur pada aplikasi ini adalah interaksi pengguna terhadap objek yang dapat menampilkan informasi objek tersebut. Aplikasi ini dikembangkan menggunakan First Person Controller dengan Unity 3D, dimana pengguna dapat melihat objek 3D dan animasi. Objek dibuat menggunakan aplikasi blender, dengan beberapa animasi 3D yang dapat dikontrol oleh pengguna. Dari hasil pengujian performasi berjalan dengan baik. Dapat memberikan kemudahan pada penggunaan serta dapat digunakan dimana saja karena dijalankan pada smartphone android. Pada aplikasi ini, diharapkan masyarakat memiliki keinginan yang inovatif atau ingin berkembang serta memudahkan dan saling bekerja sama.

\section{REFERENSI}

[1] Amiruddin, D. F. (2018)'Rancang Bangun Aplikasi Informasi Candi Ngetos Berbasis Teknologi AR pada Smartphone Android", Jurnal Pengembangan Teknologi Informasi dan Ilmu Komputer. Vol. 2, No. 8, Agustus 2018, hlm. 2651-2658

[2] Badan Pusat Statistika (BPS). (2012). Kewarganegaraan Suku Bangsa Agama dan Bahasa Sehari-hari Penduduk Indonesia (Vol. 66).

[3] Badan Pusat Statitikas (BPS). (2018). Statistika Sosial Budaya 2018.

[4] wisatasidoarjo. (2019, 18 Maret). Candi Tawang Alun. Diakses pada 19 Juni 2020, dari https://www.wisatasidoarjo.com/wisata-sejarah-di-candi-tawangalun/

[5] Clara, Agmita Rosa, (2019). Rekayasa Augmented Reality Planet dalam Tata Surya sebagai Media Pembelajaran Bagi Siswa SMP Negeri 57 Palembang. Jurnal Teknik Informatika.

[6] Coastera, A. R. E. (2014). Rancang Bangun Aplikasi Informasi Universitas Bengkulu Sebagai Panduan Pengenalan Kampus Menggunakan Metode Markerless Augmented Reality Berbasis Android. Jurnal Teknik Informatika, 7(2), 1-7. https://doi.org/10.15408/jti.v7i2.1944

[7] Furth, B. (2011). Handbook of Augmented Reality. In Handbook of Augmented Reality. https://doi.org/10.1007/978-1-4614-0064-6

[8] Hutchison, D., \& Mitchell, J. C. (1973). Lecture Notes in Computer Science. In Lecture Notes in Computer Science (Vol. 9). https://doi.org/10.1016/0020-7101(78)90038-7

[9] James, D. (2010). Crafting Digital Media. In Crafting Digital Media (Vol. 04). https://doi.org/10.1007/9781-4302-1888-3

[10] James Rumbaugh, Ivar Jacobson, G. B. (2013). The Unified Modeling Language Reference Manual. In Journal of Chemical Information and Modeling (Vol. 53). https://doi.org/10.1017/CBO9781107415324.004

[11] Pendidikan, M., Kebudayaan, D. A. N., \& Indonesia, R. (2007). Peraturan Menteri Pendidikan dan Kebudayaan Republik Indonesia Nomor 10 Tahun 2014 tentang Pelestarian Tradisi. 1-8.

[12] Shen, W. (2013). Augmented reality for E-commerce. In Applied Mechanics and Materials (Vol. 433-435). https://doi.org/10.4028/www.scientific.net/AMM.433-435.1902

[13] Soepomo, P. (2013). Membangun Aplikasi Autogenerate Script Ke Flowchart Untuk Mendukung Business Process Reengineering. Jurnal Sarjana Teknik Informatika, 1(2), 448-456. https://doi.org/10.12928/jstie.v1i2.2555 